\title{
The Systematic Development of Wiegand's Metalexicography as Demonstrated in Kleine Schriften
}

\author{
Maria Smit, Department of Music, University of Stellenbosch, Stellenbosch, \\ Republic of South Africa (msmit@sun.ac.za)
}

\begin{abstract}
This review article deals with the contents of the publication Kleine Schriften, a selection of articles written by Herbert Ernst Wiegand and compiled by Matthias Kammerer and Werner Wolski. It purports to illustrate the topics with which Wiegand engaged himself over the years, and his gradual development over a span of thirty years. Wiegand has written on many topics, but in this article mainly two aspects are discussed. Firstly, Wiegand's spelling out of an "actional-semantic approach" to lexicography is explained. He investigates the works of many authors, sometimes drawing on them, and sometimes refuting their arguments. Secondly, Wiegand's construction of a detailed text theory for lexicographical texts is discussed. Wiegand is one of the most important theoretical lexicographers of our time, and his suggestions towards metalexicographical terminology and distinctions form an essential part of present-day lexicographical practices and planning across the world.
\end{abstract}

Keywords: ACTIONAL-SEMANTIC APPROACH, DICTIONARY RESEARCH, METALEXICOGRAPHY, SEMANTICS, TEXT THEORY, UNUSUAL TEXTS, USUAL TEXTS

Opsomming: Die sistematiese ontwikkeling van Wiegand se metaleksikografie soos geillustreer in Kleine Schriften. Hierdie resensieartikel handel oor die inhoud van die publikasie Kleine Schriften, 'n seleksie van artikels geskryf deur Herbert Ernst Wiegand, en versamel deur Matthias Kammerer en Werner Wolski. Dit poog om die onderwerpe waarmee Wiegand homself deur die jare besig gehou het, aan te toon, en sy geleidelike ontwikkeling oor 'n verloop van dertig jaar. Wiegand het oor baie onderwerpe geskryf, maar in hierdie artikel word veral twee aspekte bespreek. Eerstens word Wiegand se uiteensetting van 'n "handelingsemantiese benadering" tot leksikografie verduidelik. Hy bestudeer die werk van baie skrywers, soms deur van hulle sienings te gebruik, en soms deur hulle te weerlê. Tweedens word Wiegand se opbou van 'n gedetailleerde teksteorie vir leksikografiese tekste bespreek. Wiegand is een van die belangrikste teoretiese leksikograwe van ons tyd, en sy voorstelle vir metaleksikografiese terminologie en onderskeidings vorm 'n noodsaaklike deel van hedendaagse leksikografiese praktyke en beplanning regoor die wêreld.

Sleutelwoorde: GEWONE GEBRUIK, HANDELINGSEMANTIESE BENADERING, METALEKSIKOGRAFIE, ONGEWONE GEBRUIK, SEMANTIEK, TEKSTEORIE, WOORDEBOEKNAVORSING 


\section{Introduction}

It is an almost impossible task to publish a two-volume collection of Herbert Ernst Wiegand's articles written through the years, and at the same time do justice to the wide range of topics he has dealt with. Wiegand's oeuvre currently comprises more than 390 titles. In Kleine Schriften Kammerer and Wolski collected 37 of Wiegand's articles written over a span of 30 years. They used distinct criteria in determining the selection of articles:

(a) Articles that were too long had to be omitted (for example, Wiegand 1977 and 1985) even though they may be some of his better known publications; ${ }^{1}$

(b) No articles from the series of comprehensive Handbücher zur Sprachund Kommunikationswissenschaft were included (for example Wiegand 1984a, 1989a, 1989b, 1989c, 1989d, 1989e and 1990), which actually form the axis of Wiegand's metalexicographical theory;

(c) No articles that Wiegand wrote together with other authors were included. Round about 80 articles were published in this way through the years, for example, Henne and Wiegand 1969, Ripfel and Wiegand 1988, Hausmann and Wiegand 1989, and Konerding and Wiegand 1994, and those mentioned on p. XXV of Kleine Schriften in connection with bilingual dictionary projects;

(d) Series such as Lexicographica Series Maior and Studien zur neuhochdeutschen Lexikographie (cf. p. XXIII) had been omitted;

(e) And, of course, it was not possible to include the contents of the comprehensive first volume of Wiegand's Wörterbuchforschung. Untersuchungen zur Wörterbuchbenutzung, zur Theorie, Geschichte, Kritik und Automatisierung der Lexikographie (1998). ${ }^{2}$

Even though Kammerer and Wolski published the articles in chronological order, they explain that recurring themes in Wiegand's work through the years can be traced in the two volumes. Their aim is not so much to honour a specific person and his individual accomplishments, although it is clear to anybody working in the field of dictionary research that Herbert Ernst Wiegand made an invaluable contribution in this regard. It is also not a general orientation to Wiegand's works. They rather want to indicate and unite in one publication different directions pointed out by Wiegand in course of time which reflect trends of thought in linguistics, especially with regard to sub-disciplines such as pragmatics and text linguistics. They strive to disclose Wiegand's connections with research traditions in linguistics by selecting articles that demon- 
strate the developments which took place in dictionary research and Wiegand's positioning of himself within the wider field of linguistics (Kammerer and Wolski 2000: X-XII). For example, during the 1970s he developed arguments with regard to the use of semantic features and theories about the so-called "lexicographic definition", in the process making use of many references to the work of other linguists. Kammerer and Wolski (2000: XXX) also remind the reader that Wiegand's most recent works link up with newer conceptions in the philosophy of linguistics, the cognitive sciences and cognitive psychology (frames, scripts, scenarios, prototypes, stereotypes, etc). ${ }^{3}$

Through the years Wiegand has specifically excelled at dealing in a critical way with various diverging and controversial theories, and usually demonstrated his acquired insights with carefully chosen examples, sometimes even revising his own former conceptions in reaction to other scholars' work (p. XII). ${ }^{4}$ One of Wiegand's favourite approaches is to construct his arguments by looking critically at the work of other scholars, using citations from their work, in many cases to refute or correct their arguments. ${ }^{5} \mathrm{He}$ then usually engages in complicated reasoning, finding solutions and making suggestions on which he can build his comprehensive theory of lexicography. This modus operandi is also perceptible in Kleine Schriften.

According to their introduction, the various themes Kammerer and Wolski distinguish in Kleine Schriften are Wiegand's investigations into (i) semantic theories including "actional-semantic" theory, ${ }^{6}$ (ii) practical lexicology, (iii) text linguistics, (iv) metalexicography, (v) dictionary typology, (vi) special-field lexicography, (vii) bilingual lexicography, (vii) dictionary research, and (ix) computer lexicography. They also included several isolated articles, such as "Dialekt und Standardsprache im Dialektwörterbuch und im standardsprachlichen Wörterbuch" (1986) and "Der frühe Wörterbuchstil Jacob Grimms" (1986), which they claim do not belong under any of the above-mentioned topics.

In order to unlock the contents of Kleine Schriften more comprehensibly, this article mainly focuses on two themes with which most of the selected articles can be associated. These themes are (i) Wiegand's views on meaning, or his "actional-semantic approach", and (ii) his text theory for lexicographical texts. The main aim is to demonstrate Wiegand's argumentation and gradual development of these two basic themes through the years, and how his entire lexicographical theory is based on these two important principles.

To place the articles of Kleine Schriften within the greater framework of Wiegand's theory, two illustrations are given. Figure 1 presents an overview of Wiegand's metalexicographical theory. Figure 2 features a list of the topics treated in Kleine Schriften (an adapted exposition of Kammerer and Wolski's above-mentioned classification) and the particular components of Wiegand's theory to which the topics belong. Since some articles deal with more than one topic, Figure 2 therefore only gives a very broad classification. 
Figure 1

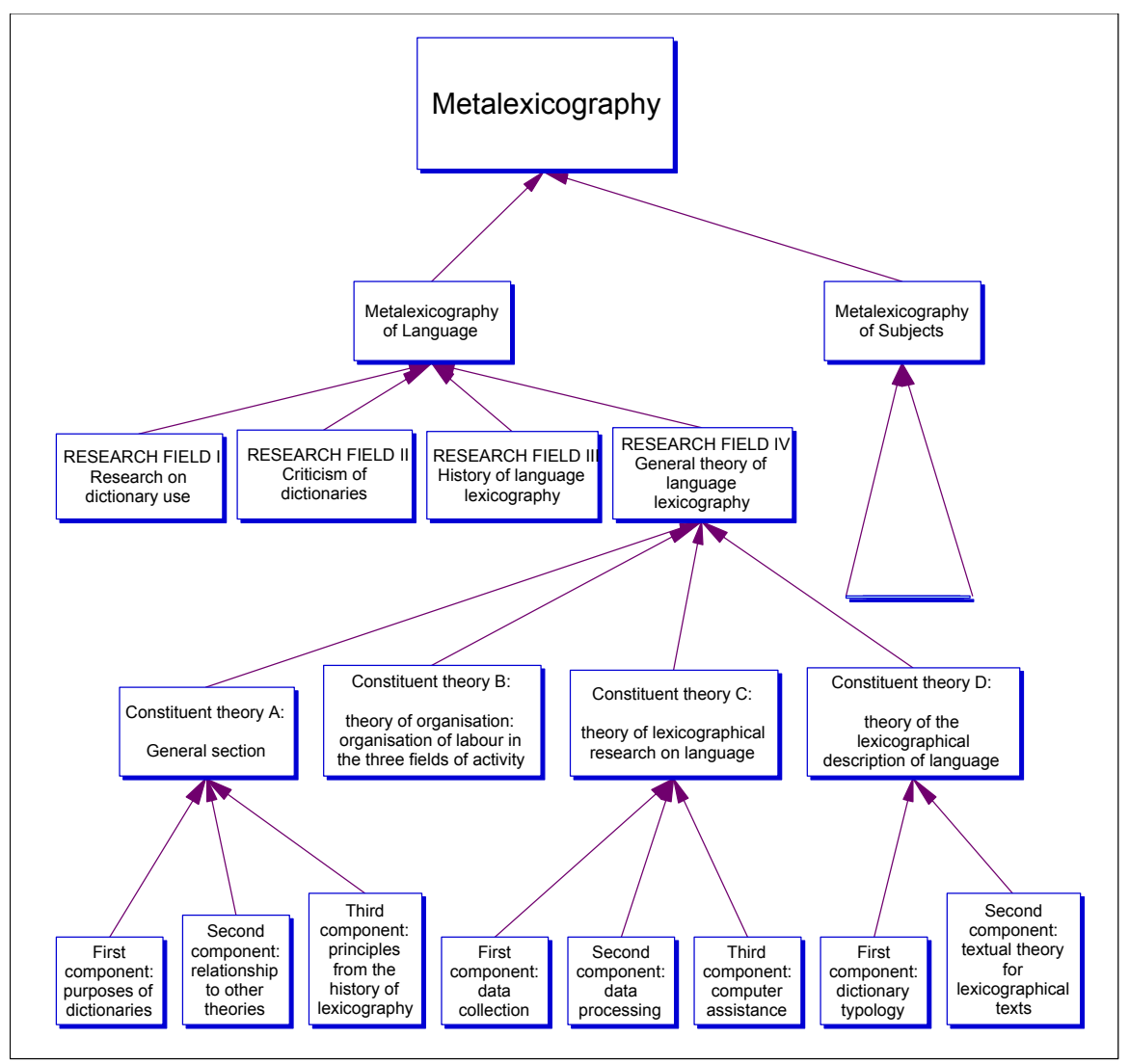

Figure 2

\begin{tabular}{|l|l|l|}
\hline $\begin{array}{l}\text { TOPICS INCLUDED IN } \\
\text { KLEINE SCHRIFTEN }\end{array}$ & ARTICLE NUMBER(S) & $\begin{array}{l}\text { COMPONENT WITHIN } \\
\text { WIEGAND'S THEORY }\end{array}$ \\
\hline Semantic Theory & $1,2,3,37$ & $\begin{array}{l}\text { Research Field IV: } \\
\text { Constituent Theory A: } \\
\text { Second component }\end{array}$ \\
\hline Practical Lexicology & $4,8,9,18$ & $\begin{array}{l}\text { Research Field IV: } \\
\text { Constituent Theory A: } \\
\text { Second component }\end{array}$ \\
\hline $\begin{array}{l}\text { Actional-semantic } \\
\text { Theory }\end{array}$ & $6,14,20,22,26,30,31,37$ & $\begin{array}{l}\text { Research Field IV: } \\
\text { Constituent Theory A: } \\
\text { Second component }\end{array}$ \\
\hline Text Theory & $5,6,7,10,15,23,24,25,27,28,29,32,34$, & $\begin{array}{l}\text { Research Field IV: } \\
\text { Constituent Theory D: } \\
\text { Second component }\end{array}$ \\
\hline
\end{tabular}




\begin{tabular}{|l|l|l|}
\hline Dictionary Typology & $11,12,13,16,17,18,19,21,25,26,27$ & $\begin{array}{l}\text { Research Field IV: } \\
\text { Constituent Theory D: } \\
\text { First component }\end{array}$ \\
\hline $\begin{array}{l}\text { Special-field Lexicog- } \\
\text { raphy }\end{array}$ & $5,7,22,26,30$ & $\begin{array}{l}\text { Research Field IV: } \\
\text { Constituent Theory D: } \\
\text { First component }\end{array}$ \\
\hline Bilingual Lexicography & 29,32 & $\begin{array}{l}\text { Research Field IV: } \\
\text { Constituent Theory D: } \\
\text { First component }\end{array}$ \\
\hline Computer Lexicography & 15,36 & $\begin{array}{l}\text { Research Field IV: } \\
\text { Constituent Theory C: } \\
\text { Third component }\end{array}$ \\
\hline $\begin{array}{l}\text { Learners' Lexicography } \\
27\end{array}$ & $\begin{array}{l}\text { Research Field IV: } \\
\text { Constituent Theory D: } \\
\text { First component }\end{array}$ \\
\hline $\begin{array}{l}\text { Research on Dictionary } \\
\text { Use }\end{array}$ & $4,14,20$ & \begin{tabular}{l} 
Research Field I \\
\hline Metalexicography
\end{tabular} \\
\hline $\begin{array}{l}\text { Criticism of Dictionaries } \\
10,15,25,28,33\end{array}$ & $\begin{array}{l}\text { Metalexicography of Lan- } \\
\text { guages }\end{array}$ \\
\hline
\end{tabular}

Of the 37 articles in Kleine Schriften, only the following are available in English: (i) numbers 15 and 24 (originally published in English); and (ii) numbers 3, 9 and 26 (included in Wiegand 1999).

\section{Wiegand's "actional-semantic" approach}

Even though Kammerer and Wolski (2000: XIII) assert that the first two articles in Volume 1 ("Synchronische Onomasiologie und Semasiologie. Kombinierte Methoden zur Strukturierung der Lexik" (1970) (pp. 1-98) and "Einige Grundbegriffe der lexikalischen Semantik" (1972) (pp. 99-124)) mainly have only historical value from a scientific point of view, it is interesting to note that the very last article in Volume 2 ("Mit Wittgenstein über die Wortbedeutung nachdenken. Gebrauch? Regel im Kopf? Ein Etwas im Kopf?" (1999) (pp. 1507-1552), deals with exactly the same issues. It is clear that the compilers connect Wiegand's most early contributions with his most recent ones, and rightly so.

In the first two articles of Volume 1 of Kleine Schriften, Wiegand uses the "structuralist terminology" popular during those days, but already also starts forming new, more appropriate terminology specific to the study of lexicographical works. Terms he uses, are, for example, "langue" and "parole", "Sem", "Noem", "Plerem", "Signem", "Monem", "onomasiology", "semasiology"; references are made to discussions about triangular and trapeze models to demonstrate relationships between "Inhaltsform" ("content form") and "Ausdrucksform" ("expression form"); etc. These two articles were written during the same period as Henne and Wiegand (1969), in which they scrutinize the 
then existing literature dealing with terminology on meaning, for example, those terms used by De Saussure, Baldinger, Heger, Katz and Fodor, and Chomsky. The main idea at that time was to get a clear picture of what the concepts "meaning" and "notion" ("Begriff") entail, and to what these terms, generally used in semantics, actually refer. Wiegand strives towards a very exact, determinable description of meanings ("Berechenbarkeit von Bedeutungen" (Kammerer and Wolski 2000: XIV)), and in the process he often, but not exclusively, uses the prevalent tools of that period, such as semantic features. By the mid-1970s, he also gradually starts using other methods in his investigations, such as communication models, which later became more popular approaches in linguistics (Kammerer and Wolski 2000: XIV). But, even in his latest articles, Wiegand still uses many of the earlier structuralist concepts and insights (cf., for example, Wiegand 2002). Nowadays Wiegand's terms are widely used in dictionary research.

In the last article of Volume 2, "Mit Wittgenstein über die Wortbedeutung nachdenken. Gebrauch? Regel des Gebrauchs? Ein Etwas im Kopf?" (1999), Wiegand also distinguishes between a "realistic" and "non-realistic" approach to semantics. Different scholars, such as Austin, Ayer, Carnap, and others are surveyed. According to him the "realistic" approach considers languages as abstract sign systems. Linguistic signs are viewed as semiotic phenomena, which convey meaning, and to which certain entities such as ideas, notions, concepts, abstract objects, classes, presentations and propositions, are assigned. Realistically conceptualised meanings can then be analysed or decomposed into smaller parts, such as semantic features and semes. The use speakers make of linguistic signs when communicating, does not play a big role in realistic approaches to meaning (p. 1511).

Wiegand explains that he does not disapprove of realistic approaches to semantics (p. 1511, note 3), but that he rather prefers a so-called "non-realistic" approach in which languages are viewed as "arsenals of tools for action" (p. 1512). According to this view, language signs are primarily tools by means of which linguistic actions can be performed. They convey meanings because they are employed according to collectively accepted rules of usage, and fulfil certain purposes while being used.

In "Synonymie und ihre Bedeutung in der einsprachige Lexikographie" (1976) (pp. 125-173), Wiegand illustrates his position on actional-semantics by means of the by now famous "Kajak" ("kayak") example (pp. 130-134), where he demonstrates that, in everyday dialogues, speakers of a language (and, by implication, dictionary users) normally do not distinguish between a particular word and the extra-linguistic entity to which that word refers. In this example, two boys, Matthias and Bobby, have a conversation in which Matthias speaks about the "kayak" he received as a birthday present. Bobby reacts by asking what a kayak is, and Matthias then answers by giving some information on what a kayak actually is, describing what it looks like. ${ }^{8}$

Wiegand argues that a dictionary user will not be able to use a word in a dictionary without some extra-linguistic knowledge (or encyclopedic knowl- 
edge) of the entity to which the word refers. That is why lexical paraphrases in monolingual dictionaries should not be based solely on the analysis of semantic features. Lexical paraphrases should also inform dictionary users of the "extension" (p. 133, note 22), or encyclopedic aspects, of a word to enable them to use the particular word appropriately and in the right context(s), according to the usual semantic rules.

Another example Wiegand uses to illustrate his concept of meaning, is found in the fourth article of Volume 1, "Einige grundlegende semantisch-pragmatische Aspekte von Wörterbucheinträgen" (1977) (pp. 174-236). Here, he tries to explain what people speak about in everyday conversation when referring to the meaning of linguistic expressions, and how they speak about this. Normally, he contends (p. 201), people do not distinguish between language and world. However, they need reference rules in order to use words correctly or "in a usual way". Reference rules are "intra-individual" rules (p. 671), by means of which people can communicate with each other.

Wiegand often uses the concepts "usual texts" and "unusual texts" (for example, p. 204). To illustrate what he means by these expressions, he uses another very famous example, namely the word "Rappe". Wiegand (p. 204) subscribes to Grice's approach, and explains that if a speaker uses a text in an "unusual" way, he/she says something but may mean something different. In his example, the father of the boy uses the word "Rappe", which normally (under "usual" circumstances) refers to a black horse. The father, in a game, calls his son "Rappe", because the son indicated that he is imitating a horse. This, of course, does not mean that the boy is a horse. In this example, the father breaks the normal reference rules and does not use the word "Rappe" in the "usual" way. Dictionary compilers could not keep this type of "unusual" texts in mind when they formulate lexical paraphrases.

Wiegand's argumentations in connection with "usual texts" and "usual contexts of naming" are also developed in "Pragmatische Informationen in neuhochdeutschen Wörterbüchern" (1981) (pp. 335-432), included as the eighth article in Volume 1. Here Wiegand starts to distinguish between "knowledge 1" (i.e. competence with regard to the semantic rules of reference) and "knowledge 2" (i.e. competence with regard to pragmatic rules in order to use expressions appropriately), which gives a useful tool for future explorations and could be used instead of referring to "denotative" and "connotative" features. ${ }^{9}$

In the article "Was eigentlich ist Fachlexikographie? Mit Hinweisen zum Verhältnis von sprachlichem und enzyklopädischem Wissen" (1988) (pp. 458511), Wiegand not only structures special-field lexicography, but also develops important theoretical assumptions on action theory and text theory, and lexicographical concepts such as "genuine purposes of dictionaries". Although the main focus of the article is to classify special-field dictionaries into distinct types ("fachliches Sprachwörterbuch" (special-field language dictionary), "fachliches Sachwörterbuch" (special-field encyclopedia), and "fachliches Allbuch" (a combination of the first two)), Wiegand sheds further light on the issue that was investigated in the article "Pragmatische Informationen ..." (1981), namely 
types of knowledge. "Knowledge 1" now becomes "gegenstandskonstitutives Bedeutungswissen" (p. 871).

A later article concentrating on special-field lexicography included in Volume 2 is "Zur Unterscheidung von semantischen und enzyklopädischen Daten in Fachwörterbüchern" (1994) (pp. 1106-1127), in which the earlier distinctions between the different types of special-field dictionaries are investigated further. In the field of special-field lexicography, Wiegand distinguishes different types of knowledge, namely (i) special-field encyclopedic factual knowledge ("fachenzyklopädisches Sachwissen"), (ii) special-field object-constituting meaning knowledge ("fachenzyklopädisches gegenstandkonstitutives Bedeutungswissen"), and (iii) non-encyclopedic meaning knowledge ("nichtenzyklopädisches Bedeutungswissen"). ${ }^{10}$ It is, however, also useful to apply these distinctions in general lexicography, especially the notion of "object-constituting meaning knowledge".

Wiegand (p. 870) illustrates this notion when he states that, from the point of view of an actional-semantic approach, a lexical paraphrase can be seen as a "lexicographical rule formulation". In a lexical paraphrase, one formulates the reference rules and predicate rules for the use of a non-special-field lemma sign, so that the correct use of that lemma sign will be compatible with the usual contexts of naming. The language user will, therefore, have knowledge that something is something specific, and not something else. This type of knowledge Wiegand calls "object-constituting knowledge", because it brings the specific object to mind when the expression is uttered.

In the article "Über usuelle und nichtusuelle Benennungskontexte in Alltag und Wissenschaft" (1996) (pp. 1278-1310), included in Volume 2, Wiegand once again discusses the difference between everyday dialogues and scientific communication. Everyday objects are named, and there exists a socially collective accepted agreement among language users about the names of objects. ${ }^{11}$ This agreement enables people to know what other people mean when they use certain words "in a usual way". When people perform a referential action ("Referenzhandlung"), it means that they use a referential expression ("Referenzausdruck"), in other words, they refer to something. In Wiegand's terms, the action of the type TO REFER TO SOMETHING ("AUF ETWAS REFERIEREN") is a linguistic action, performed by one speaker who utters a referential expression with the purpose of at least one other speaker identifying the object of reference (p. 1291). Reference actions are, therefore, genuine actions of dialogue ("genuine dialogische Handlungen") which have to be oriented towards the knowledge of at least one other speaker if they are to be successful. For example, under normal circumstances, a person A would not perform a reference action which he/she knows in advance would not be understood by person $\mathrm{B}$.

In this article, Wiegand once again uses some examples. He claims, for instance, that using the name "Pferd" ("horse") to refer to a horse, is governed by rules of correct, "usual" usage, and when people know these collective rules of naming and know how to use this name, it follows that at least the "object- 
constituting meaning knowledge" (which forms part of the encyclopedic knowledge) ${ }^{12}$ is conveyed (pp. 1297-1298). If a speaker A is then successful in using an utterance, it means that the other communicator, speaker B, could derive the meaning of the particular utterance. In order to be able to do this, speaker B has to have a special "linguistic action knowledge" ("Sprachhandlungswissen"), which is possible because the "object-constitutive meaning knowledge" of the utterance was present and the usual reference rules for the particular utterance had previously been acquired (p. 1301). ${ }^{13}$

It could, of course, happen that the meaning knowledge ("Bedeutungswissen") of two speakers differs, so that an utterance could have a different actual meaning for the two communicating speakers, even when it is used according to the "usual" rules. In every communication process where language is used between two speakers, the individual meaning knowledge of one speaker is aligned with the exteriorized meaning knowledge of the other, present in the rule-bound usage of both. As long as this process of comparison is free of disturbances, speakers are not concerned about word meanings. But when communication conflicts arise, word meanings become important, because it is usually impossible to solve such conflicts without solving the problem of word meanings (p. 1534).

In the third article of Volume 1, "Synonymie und ihre Bedeutung in der einsprachige Lexikographie", first published in 1976 (pp. 125-173), the implications of Wiegand's semantic approach for lexicography begin to become clear. Wiegand considers the formulation of dictionary entries as a "linguistic action", but is opposed to the idea that a dictionary entry contains a so-called "definition" in the same way as this term is used in scientific language. Wiegand refutes the idea of using the term "definition" in general lexicography. He states that dictionaries are the result of lexicographers' "writing actions" about the codified language and also about objects (p. 201). He rather prefers the expression "lexical paraphrase" to denote a dictionary entry containing the meaning description, but even then, he does not merely rely on the analysis of semantic features (p. 131, note 18) for the formulation of this lexical paraphrase. Later, in his text theory, Wiegand prefers the expression "Bedeutungsangabe" ("meaning item") for this section of the dictionary article. ${ }^{14}$

Some of Wiegand's earlier articles, a number of which are included in Volume 1, also deal with special-field lexicography. These are, for example, "Kommunikationskonflikte und Fachsprachengebrauch" (1979) (pp. 237-263), and "Bemerkungen zur Bestimmung metakommunikativer Sprechakte" (1979) (pp. 264-291), which respectively encompass investigations into types of communication conflicts in special-field languages and general communication conflicts and interruptions. In the latter article, Wiegand takes the findings of discourse analysis and speech act theory of that time into account by discussing the viewpoints of, amongst others, Meyer-Hermanns, Searle, Wunderlich, Bühler, Grice, Bales and Betten, in order to make certain important distinctions with regard to speech acts and successful reciprocal communication between humans. He bases his discussion on about 150 everyday dialogues which he recorded. In 
this article, Wiegand once again discusses the "Kajak" example as representative of many other everyday dialogues, and draws some important conclusions. Some of these are: (i) human speech acts or communication by means of language can result in communication conflicts, because people may have certain knowledge gaps ("Wissenslücken"), (ii) humans "acquire" certain ways of dealing with such communication conflicts by developing "interactional-reflexive" actions ("interaktionsreflexive Handlungen"), (iii) humans want to be successful when communicating with other people, and (iv) humans know when to use these "interactional-reflexive" actions when there is danger of communication not being successful.

When these are applied to lexicography, as in the situation of consulting a dictionary, users may have a search question of the type "WAS BEDEUTET X?" ("WHAT DOES X MEAN?") (with X as variable for lexical items). In usual naming contexts, a dictionary would then ideally fill the individual's knowledge gap, keeping the everyday lexicon stable in the process (p. 1303).

To demonstrate the types of information that he deems necessary for dictionary users, Wiegand (pp. 212-219) discusses the example of "Weberei" ("weaving") in the early article "Einige grundlegende semantisch-pragmatische Aspekte von Wörterbucheinträgen" (1977) (pp. 174-236). The word "Weberei" is used in a general as well as a specialized sense, and Wiegand suggests that one could include more information than mere semantic features. To indicate the "special-field" use of "Weberei", one could even give a short historical introduction to the art of weaving, together with bibliographical references. An interesting idea is Wiegand's suggestion about using a so-called "lexicographical narration". This means that one systematically relates how a loom is built (for example, an expert telling non-experts), so that the user can get an idea of what the components are, and what they look like. Even though this process is specifically useful for learners' dictionaries, it illustrates Wiegand's emphasis on the fact that users need extra-linguistic knowledge in addition to knowledge about semantic features.

In lexicography, one has additionally to take the purpose of the particular dictionary into account to determine the type of knowledge that should be conveyed to the reader. Wiegand claims that different purposes of description need different methods of description (p. 1541). That which is considered the "description of meaning", is mostly nothing more than a description of the rulebound usage, or an example of this. This is particularly true when the addressees are individuals of whom it is accepted that they do not know the meaning of the lexical items. These "descriptions" can then enable them to obtain knowledge about a word's meaning and to know how to use the word correctly.

A very complete exposition of Wiegand's views on action theory can be found in the article "Zur handlungstheoretischen Grundlegung der Wörterbuchforschung" (1987) (pp. 704-748). In this article, Wiegand, approaching dictionary use as a set of user actions, explains and develops this area of research by drawing up an "actional-theoretical" framework (p. 709). In the process, he formulates numerous definitions and distinctions, at the same time giving a 
critical survey of the texts on analytical action theory available at the time.

One of the best-known examples used by Wiegand is the one of "Frosch" ("frog") (pp. 709-712). ${ }^{15}$ Wiegand indicates that he deliberately chooses examples which are not specifically related to dictionary research. The example illustrates how, in an everyday dialogue, two persons speak about what a certain person Hans has done: Hans hat den Frosch gequält ("Hans has tortured the frog"). This activity by Hans is described by means of a linguistically uttered interpretation of his activity. That which Hans has done, can be considered as a case which can be referred to by means of the usual rules of usage, utilising the expression einen Frosch quälen ("to torture a frog") (p. 710). All such activities, to which one can refer in usual texts by using the expression einen Frosch quälen, belong, as actions, to the action type EINEN FROSCH QUÄLEN ("TORTURE A FROG").

In the same way, one can also get user actions relating to dictionary use, which can belong to an action type such as EIN WÖRTERBUCH BENUTZEN ("USING A DICTIONARY"). For every action, there is an internal action context (p. 716) such as the particular reason why it is performed, and the purpose. For example, if one wants to find out the reason why a person has used a dictionary, one can formulate a why-question such as WHY HAS HE USED THE DICTIONARY? ${ }^{16}$ In the same way, one can also interpret the consequences of the user action, for example, by formulating a question such as WITH WHICH CONSEQUENCES HAS HE USED THE DICTIONARY? (p. 717). Wiegand concludes that user actions belonging to the action type USING A DICTIONARY have many features (p. 718). These are: (i) subject of the action (WHO?), (ii) result of the action (which determines the action type) (WHAT?), (iii) modality of the action (HOW?), (iv) external context of the action (including circumstances under which the action is performed (UNDER WHICH CIRCUMSTANCES?), time of the action (WHEN?), duration of the action (HOW LONG?), and place of the action (WHERE?)), (v) internal context of the action (including the purposes of the action (which are attained when the intended results are obtained) (FOR WHAT?), reasons for the action (WHY?), and incentive for the action (OUT OF WHICH CAUSE?)), and (vi) consequences of the action (WITH WHICH CONSEQUENCES?). Each of these features is included in Wiegand's so-called actional-theoretical structure of dictionary use (pp. 719-721).

In Kleine Schriften, one gets a good overview of Wiegand's gradual development of his actional-semantic approach to lexicography, even though many of his articles which give more detail on this topic, are not included.

\section{Text theory}

In early articles such as "Synonymie und ihre Bedeutung in der einsprachigen Lexikographie" (1976) (pp. 125-173), Wiegand already states that there is a lack of an "empirically-based sociology about dictionary users". He gradually develops such an empirically based theory, which later becomes one of the 
principles of his metalexicography.

The fourth article in Volume 1 has as subtitle "Ein Beitrag zur praktischen Lexikologie" ("A Contribution to Practical Lexicology"), as does the article "Pragmatische Informationen in neuhochdeutschen Wörterbüchern ..." (1981) (pp. 335-432). Wiegand's aim was to devise, by means of investigating plausible ways of linguistic explanation and description, more precise suggestions for designing lexicographical texts. Apparently there has always been a huge gap between research in lexicology and lexicographical practice. This also has led to questions about the relationship between theory and practice: whether lexicology and lexicography both are theories. ${ }^{17}$

One of Wiegand's approaches is to analyse different types of dictionaries, in order to determine which types of information they contain, and which different methods these dictionaries use in presenting data. These analyses were used to draw up, amongst others, his (i) dictionary typology, (ii) his theory of dictionary use, and (iii) his theory of lexicographical texts. Examples of articles in Kleine Schriften which contain such analyses, are (i) 4, 8, 9, and 26 (content of dictionary articles), (ii) 10, 23, 24, 25, 27, 28, 29, 32, 34 and 35 (structure of dictionary articles), and (iii) 11, 13, 17, 19, 21, and 22 (dictionary characteristics and typology). It is impossible to give attention to all of these issues within the scope of this article. Only some short comments are therefore made on Wiegand's framework for research on dictionary use, and then more detail is given about his approach to text theory. ${ }^{18}$

\subsection{Wiegand's framework for dictionary use}

The article "Fragen zur Grammatik in Wörtbuchbenutzungsprotokollen. Ein Beitrag zur empirischen Erforschung der Benutzung einsprachiger Wörterbücher" (1985) (pp. 560-618) is a precursor to "Zur handlungstheoretischen Grundlegung der Wörterbuchforschung" (1987), in which Wiegand outlines a framework for research on dictionary use. The latter article explains many terms such as experienced users, potential users, ways of dictionary use, user questions, etc., and different types of dictionary use are systematically classified. ${ }^{19}$ These articles also connect with the much later article "Über primäre, von Substantiven 'regierte' Präpositionen in Präpositionalattributkonstruktionen" (1996) (pp. 1311-1338), included in Volume 2, in which Wiegand constructs a framework of types of user questions and many terms that should be used in this regard (cf., for example, pp. 724 and 746).

\subsection{Wiegand's text theory for lexicographical texts}

Wiegand formulates certain hypotheses with regard to the lexicographical layout of different types of dictionaries by analyzing many different dictionaries and dictionary articles. These deliberations enable him to draw up a very detailed framework for the structure of dictionary articles, with the aim of 
making future dictionaries more user-friendly. ${ }^{20} \mathrm{He}$ uses the "mathematical structure concept" of Bourbaki as well as language from set theory to marshal his findings (p. 968). ${ }^{21}$ According to Wiegand, his theory of lexicographical texts has three parts: (i) the production of texts, (ii) the structure of texts, and (iii) the reception of texts (p. 968).22

In the article "Was ist eigentlich ein Lemma? Ein Beitrag zur Theorie der lexikographischen Sprachbeschreibung" (1983) (pp. 458-511), Wiegand introduces numerous new terms which refer to lexicographical practice. This wellknown article is an important contribution to his text theory for lexicographical texts. Wiegand strongly indicates his preferences for certain expressions, for example, "dictionary article" instead of "dictionary entry". He defends his viewpoints by citing numerous examples from dictionaries, and by giving citations from the work of other authors. Other terms discussed are, for example, "lemma", "lemma collection", "guiding element", "guiding form", "micro- and macrostructure", "partial lemma", "nesting lemma" and "niching lemma". He introduces no less than 52 metalexicographical terms in this article.

In his article "Metalexicography. A Data Bank for Contemporary German" (1986) (pp. 619-634), Wiegand writes about computer lexicography. But he also deals with important aspects regarding text theory for lexicographical texts. He lists text type segments (cf., for example, p. 623) which can be used in dictionaries, and makes suggestions on how one could proceed in compiling an electronic database, based on different text types. This article in English is a good directive to illustrate Wiegand's line of thought.

The approach towards text linguistics in the article "Zur handlungstheoretischen Grundlegung der Wörterbuchforschung" corresponds with that in "Wörterbuchartikel als Text" (1988) (pp. 877-950). These two very important articles laid the foundation for argumentations used in many of Wiegand's following publications, for example, his treatment of special-field lexicography, his text theory for the structural organization of dictionaries, and his magnum opus, Wörterbuchforschung (1998).

Not only is the article "Wörterbuchartikel als Text" (1988) connected with Wiegand's earlier attempt towards structuring a general theory of lexicography, ${ }^{23}$ but he also states here that new and fruitful insights for dictionary research can be obtained if text theory categories are used (p. 950). Dictionaries are carriers of text types: the "lemma" could, for example, be compared to the text type "title" (p. 932). Different types of dictionaries show different article structures and different degrees of standardisation. Dictionary articles consist of partial texts which he calls "data types" (p. 907). ${ }^{24}$ For the sake of scientific inquiry, it is possible to present such data types by means of tree structures, as he often does (cf., for example, pp. 916-917).

Lexicographical partial texts should be seen as "functional parts in a greater context" (p. 950). One should therefore not consider the individual items in lexicographical texts as isolated linguistic units, but dictionary articles (the most important type of partial texts) should be investigated with regard to 
their integration within the text as a whole. Wiegand states that a text theory for lexicographical texts also offers a tool for the development of new article structures, and the examination of lexicographical instruction books and sample articles. Worthwhile insights that can enhance the computerisation of existing dictionaries, or help with the planning of a lexicographical system can also be obtained.

The article "Printed Dictionaries and their Parts as Texts" (1991) (pp. 9511062) clearly takes these issues further. By means of graphic illustrations and different notational conventions, Wiegand gives a very comprehensive overview of the growing interest in the textual properties of lexicographical texts in Europe. ${ }^{25}$ Being in English, this article is of course most useful to Englishspeaking readers. Wiegand lists aspects of his text theory for lexicographical texts: (i) criteria for the textuality of lexicographical texts and representation form of textuality, (ii) text condensation, propositional density and expansion of texts, (iii) kinds and degrees of standardisation of lexicographical texts, and (iv) order structures of lexicographical texts, namely: textual book structure, textual word list structure; inner and outer access structures including rapid access structures; hierarchical and precedential article structures; hierarchical and precedential microstructures and item structures; kinds of microstructures, such as simple, expanded, composed, rudimentary, listing, integrated, partially integrated, non-integrated and the possible combinations; partial structures of microstructures, item structures and article structures; and the microstructure programme of a dictionary and the grammar for establishing microstructures. ${ }^{26}$ Other structures studied are scope structures, cross-reference structures, addressing structures, cohesion structures, theme-rheme structures and coherence structures.

In "Über die Mediostrukturen bei gedruckten Wörterbüchern" (1996) (pp. 1163-1192), Wiegand sketches the developments within the field of systematic dictionary research since the article "Was ist eigentlich ein Lemma?" (1983). He proceeds from the assumption that dictionaries are text type carriers of which the texts, text parts and text segments have a specific relationship to each other. Clear distinctions are made between ordering structures, such as macrostructures, access structures, text constituent structures, addressing structures, cohesion structures, etc., leading to intricate illustrations of structures.

The term "mediostructure" is a newer addition to Wiegand's arsenal of lexicographical concepts. The "dictionary-internal mediostructure" links the knowledge elements which are represented by means of texts in the various sections of the dictionary when it is not possible to observe them all at the same time, as, for example, in cross-references (pp. 1164, 1168). In this article, Wiegand distinguishes between different types of mediostructures, such as (i) dictionary-internal mediostructures (cross-referring within the same dictionary), (ii) dictionary-linking mediostructures (cross-references linking lexicographical data in one dictionary by means of references to data in another dictionary), (iii) source-related mediostructures (cross-referring to external sources), and 
(iv) literature-related mediostructures (cross-referring to literature). Wiegand systematically discusses various types of "cross-reference mediating items" ("Verweisvermittelnde Angaben") and methods of cross-referring (cf., for example, p. 1191 for a list of classes of cross-references, and the accompanying terminology). He concludes that it is better nowadays to use a computer system to set up cross-references, because formerly, when cross-references were written manually, there were many mistakes and inconsistencies. This could lead to the qualitative improvement of dictionaries and to enriched mediostructural programmes (p. 1192).

The article "Das Konzept der semiintegrierten Mikrostrukturen. Ein Beitrag zur Theorie zweisprachiger Printwörterbücher" (1996) (pp. 1193-1277) is very complicated. To understand it well, one has to be very familiar with Wiegand's metalexicography. Even though the article uses examples from bilingual lexicography, it is an important contribution to the text theory of lexicographical texts in general. Wiegand argues that it not necessarily true that one would need at least four translation dictionaries for each language pair, as some translation scholars believe. ${ }^{27}$ If one could compile a dictionary in such a way that it contains all the necessary data, ordered in a clearly observable and easily retrievable way, one dictionary could serve all the different purposes of active and passive language use. This means that it may be fruitful to use semi-integrated article structures.

Wiegand explains what these are by means of discussing several wellknown types of microstructures, such as integrated, non-integrated and partially integrated microstructures (pp. 1197-1203). For example, a "simple hierarchical microstructure is integrated when (i) each item of a particular monolingual dictionary not belonging to the comment on form lies in the lexicalsemantic area of a specific meaning, and when (ii) each of these items belong to the same semantic sub-comment as the one by means of which the meaning is conveyed, so that each of the items is in the direct scope of this 'item giving the meaning"' (p. 1198). ${ }^{28}$ This means that, in simple cases of integrated microstructures, the semantic sub-comments are part of the comment on semantics.

On the other hand, a simple microstructure of a monolingual dictionary is called "non-integrated when (i) all the 'items giving the meaning' which are addressed to the 'lemma sign form item', are present in the first semantic subcomment of the semantic comment, and when (ii) all co-text items (such as example items, collocation items and all other types of phraseological items) as well as all items which are addressed to these, are allotted according to a system (which is explained in the metatext of the dictionary) to different semantic sub-comments which follow each other and which are called 'semantic subcomments on the co-text'" (p. 1220). This means that there are different sets of items after the "item giving the meaning", following each other, each with different types of data.

Other microstructures Wiegand discusses are in monolingual dictionaries, partially-integrated microstructures (with pre-integrate and with post-inte- 
grate) and over-annexed and under-annexed microstructures, and in bilingual dictionaries, mixed-integrated microstructures and non-integrated microstructures.

Wiegand claims that there are no monolingual dictionaries in German containing semi-integrated microstructures. This type of structure, however, would mean that integrated and non-integrated microstructures are combined, having the advantages of both types of microstructures, and avoiding their disadvantages (p. 1232). Firstly, there are advantages regarding the internal access time: it takes considerably less time to find the lexical text data. Wiegand points out that one can prove this empirically (pp. 1232-1233). This would enhance the user-friendliness of monolingual dictionaries, especially general comprehensive dictionaries and learners' dictionaries (cf. also p. 1240).

Wiegand compiles his own semi-integrated article as illustration (cf. p. 1234): he uses different "text blocks" which display "text block beginning signals" ("Textblockanfangsignale") such as numbers printed in bold, and "text block ending signals" ("Textblockendsignale") such as a full-stop. This means that, being bordered at the beginning and the end from the other article text constituents in the particular dictionary article, they can be detected more easily. The article text is, therefore, demarcated by means of typographical microarchitectural indicators ("typographische Mikroarchitekturanzeiger") (p. 1233). Wiegand notes that this type of article is "internally bi-accessible" ("intern biakzessiv") (p. 1240), which means that there is more than one search path: one leads to the first part of the article which contains seme-specific data, and the other leads to the items containing the co-text classes. In computer lexicographical terms, one would therefore be able to compile "multiple window articles" ("Mehrfensterartikel"), in which each window would contain a distinct search area which exhibits the specific text data to convey answers on search questions specifically belonging to the window classes (p. 1241).

In the development of the theory of dictionary research, Wiegand has coined numerous important terms for theoretical concepts. Over the years, however, he has sometimes changed certain details in view of newer insights and in reaction to criticism by other authors. In one such article, "Altes und Neues zur Makrostruktur alphabetischer Printwörterbücher" (1998) (pp. 14281453), he more precisely defines terms he introduced in earlier publications, such as "grouping", "article nest", and "straight-alphabetical macrostructures" ("glattalphabetische Makrostrukturen"). He points out that in earlier publications, he worked with Carnap's structural approach, but that since 1989, he started to prefer the structural approach of the Bourbaki mathematician group (p. 1429). The latter approach enables the development of a more precise, concrete structure in which the carriers of the guiding element ("Leitelementräger"), for example the lemmata, also form part of the macrostructure of dictionaries. In the former approach, this was not possible.

Other articles dealing with dictionary typology also exhibit early traces of Wiegand's investigation of text condensation. One example included in Vol- 
ume 1 is "Zur Geschichte des deutschen Wörterbuchs von Hermann Paul" (1983) (pp. 512-527). However, especially in the article "Lexikographische Textverdichtung. Entwurf zu einer vollständigen Konzeption" (1998) (pp. 14541489), Wiegand deals extensively with the concept of text condensation in dictionaries. ${ }^{29} \mathrm{He}$ claims that it is possible precisely to determine the degree of textual condensation in dictionary articles by using mathematical calculations (p. 1455). Because of this possibility, the extent of user-friendliness of dictionaries can be determined by devising formulas based on these calculations. This will, furthermore, enable the planning of dictionaries, and ensure that the compilation of dictionary articles could be a learnable skill. Wiegand distinguishes between (i) internal text condensation (which concerns all lexicographical partial texts with a carrier of the guiding element (e.g. lemmata) as well as register entries of which the keyword is the carrier of the guiding element) and (ii) external text condensation (which concerns all lexicographical partial texts with an outer access structure, i.e. the central word list especially) (p. 1456).

To illustrate Wiegand's line of thought, the following article of Flöte ("flute") can serve as example:

Flöte, die; -, -n rohrformiges Blasinstrument (aus Holz): die F., auf der F. blasen; er spielt (die) F.

Certain "full texts" can be deduced from this article, some of which are:

- Dictionary article on Flöte.

- The correct spelling of Flöte is |Flöte|.

- The form of the noun singular is Flöte.

- Flöte has the accent on the first syllable.

- The accent syllable of Flöte is long.

- The correct article for Flöte is die.

- The gender of Flöte is feminine.

- Flöte is a noun.

- The form of the possessive singular is Flöte.

- The form of the noun plural is Flöte.

- Flöte is not pragmatically marked.

- Flöte means something like rohrformiges Blasinstrument or rohrformiges Blasinstrument aus Holz ("pipe-shaped wind instrument" or "pipe-shaped wind instrument made of wood")

- Examples for the use of Flöte are: die Flöte blasen, auf der Flöte blasen, er spielt die Flöte, er spielt Flöte.

Most dictionaries standardize the way in which they use text condensation. This has to be explained in the metatext of the dictionary (e.g. the user's guide or the list of abbreviations) (p. 1463). Users have to be acquainted with the conventions in order to be able to extract information from the presented data in 
the condensed texts. The full texts are of course omitted to save space, and certain symbols are used instead.

To calculate the degree of condensation, Wiegand suggests that the number of full text segments is calculated. For example, in the case of Flöte, the full text part, "The correct spelling of Flöte is |Flöte|.", has ten text segments (including the full-stop). According to Wiegand, the entire full text of this dictionary article has 77 segments in German. One therefore divides 77 by 10, which means that the proportional condensation of the dictionary article at hand is 7,7 . The greater the value of this quotient, the less the proportional condensation of the full text or full text parts.

This section dealt with Wiegand's gradual development of a text theory for lexicographical texts. Even though it is not possible to deal with all the intricate distinctions Wiegand has made, it was attempted to show how Wiegand went through different stages of reasoning in order to devise his text theory.

\section{Concluding remarks}

In this article, the content of the publication Kleine Schriften was discussed. An attempt was made to illustrate Wiegand's lines of thought through the years, which shaped his theory of dictionary research. Firstly, Wiegand used structuralist terminology, but gradually started coining his own. He approaches semantics from the point of view of action theory, and this affects his view of which types of information different dictionary types should contain. Secondly, Wiegand develops a comprehensive theory for lexicographical texts, based on his belief that dictionaries should be useful. His impressive investigations into dictionaries and dictionary articles led him thoroughly to understand the different textual structures in dictionaries and dictionary articles. Because of various subtle distinctions, his theory enables lexicographers to compile better dictionaries in future. Wiegand's classifications and characterisation of text types within the text theory for lexicographical texts are now widely used in lexicographical practices and in the planning of new dictionaries.

\section{Notes}

1. English translations of Wiegand (1977 and 1985) are, however, included in Semantics and Lexicography. Selected Studies (1976-1996), edited by Immken and Wolski (1999). Cf. also Louw (2000) for an article on this English publication.

2. Cf. Smit (2001) for a review article of this publication.

3. Cf., for example, Konerding and Wiegand (1994), where the issue of frames is investigated to determine their usefulness for lexicography.

4. Cf., for example, p. 1528, note 15 and p. 1531, note 16 in Volume 2, where Wiegand admits that he changed his viewpoints after having read Keller.

5. Cf. also Henne and Wiegand (1969) and Wörterbuchforschung (Wiegand 1998) for examples of 
this approach.

6. It is very difficult to translate the German word "handlungssemantisch". Immken and Wolski (1999: 4) use the expression "actional-semantic approach". This follows the expression used in Wiegand (1992: 236). For lack of a better translation, the expression "actional semantics" will therefore be used in this article.

7. Although Wiegand uses the terms "langue" and "parole" in his early publications as well as in the more recent ones (cf., for example the last article in Volume 2 of Kleine Schriften, and also in "Zur Aequivalenz in der zweisprachigen Lexikographie. Kritik und Vorschläge" (2002)), Henne and Wiegand (1969: 137) use the expressions differently from De Saussure by making even finer distinctions.

8. For an English version of Wiegand's thoughts in this regard, cf. also Wiegand (1992) or Wiegand (1999: 175-289).

9. Cf. also p. 1287, where Wiegand states that he has abandoned the use of the predicate "denotative" after Lyons had made finer distinctions.

10. In Immken and Wolski"s translation included in Wiegand (1999: 297ff), the expression "domain-specific dictionaries" is used as translation for "Fachwörterbücher". In the present article, the expression "special-field" is preferred to refer to "subject-field dictionaries".

11. Wiegand (p. 1535) calls these agreements "silent conventions" amongst a community of persons.

12. Cf. also p. 871 for a discussion of this type of encyclopedic knowledge.

13. Wiegand (p. 1533) notes that this knowledge about the rules of "usual" usage need not be complete.

14. Cf. especially Wiegand (1989e: 539-552) for a detailed argumentation on why he finds the expressions "lexicographical definition" and "lexicographical explication" problematic. Wiegand (1992: 235-243) is an excellent English version dealing with the same issues (also published in Wiegand 1999: 253-260).

15. Wiegand also expanded greatly on the so-called "Frosch" example in Wörterbuchforschung (1998).

16. Here Wiegand's examples refer only to males.

17. Cf. Wiegand (1998: 13-256) for a detailed discussion on this issue.

18. Cf. Wiegand (1984b) for an English version of his exposition of the general theory of lexicography.

19. In Wörterbuchforschung (1998), Wiegand expands greatly on this publication. Cf. also Ripfel and Wiegand (1988).

20. Cf. p. 1455, note 1, for references to Wiegand's publications which dealt with lexicographical text theory.

21. Cf. Bourbaki, N. 1958. Éléments de mathématique. Paris: Hermann. (English translation: Bourbaki, N. 1968. Elements of Mathematics: Theory of Sets. Paris: Hermann/Reading, MA: AddisonWesley.)

22. Cf. also Wiegand (1992) or Wiegand (1999: 203-282) for an English version by Immken and Wolski of Wiegand's text theory.

23. Cf. also Wiegand (1983 and 1989b) as well as article 10 "Deutsch-Usbekisches Wörterbuch" in Kleine Schriften for similar discussions.

24. Cf., for example, p. 907, where Wiegand illustrates some data types of the dictionary article "Bestand" from the Great German-Chinese Dictionary. It is important to note that Wiegand distinguishes between "data" and "information". The former are the items in a dictionary article, 
and these data types convey the information that a user needs. Cf. Wiegand (1998: 160-171) for a discussion on this distinction.

25. Cf. also Wiegand (1991) for a detailed exposition of article texts.

26. Cf., for example, p. 974, pp. 1058-1062 and 1405-1409 for lists of symbols and descriptions that Wiegand uses in his text theory to present different items in dictionary articles.

27. Cf. p. 1241 for a list of authors on translation theory who dealt with the "active-passive" issue in translation and its implications for bilingual lexicography.

28. Cf. also Wiegand (1989d) for a detailed discussion of microstructures.

29. "Text condensation" is the expression used here, even though Wiegand distinguishes between "Textverdichtung", "Textkondensierung" and "Textkomprimierung" in German (p. 1488). However, he states clearly that he is not interested in forming terminology in English. He is only concerned with the formation of terminology for German lexicography. He feels that the formation of English terminology should be done by native speakers of English (p. 1454, note $^{*}$.

\section{Bibliography}

Hausmann, F.J. and H.E. Wiegand. 1989. Component Parts and Structures of General Monolingual Dictionaries: A Survey. Hausmann, F.J. et al. (Eds.). 1989-1991: 328-360.

Hausmann, F.J., O. Reichmann, H.E. Wiegand and L. Zgusta (Eds.). 1989-1991. Wörterbücher: Ein internationales Handbuch zur Lexikographie / Dictionaries: An International Encyclopedia of Lexicography / Dictionnaires: Encyclopédie internationale de lexicographie. Berlin/New York: De Gruyter.

Henne, H. and H.E. Wiegand. 1969. Geometrische Modelle und das Problem der Bedeutung. Zeitschrift für Dialektologie und Linguistik 36: 129-173.

Kammerer, M. and W. Wolski (Eds.). 2000. Zur Einführung. Wiegand, H.E. 2000: IX-XXX.

Konerding, H.-P. and H.E. Wiegand. 1994. Framebasierte Wörterbuchartikel. Zur Systematisierung der lexikographischen Präsentation des Bedeutungswissens zu Substantiven. Lexicographica 10: 100-170.

Louw, P. 2000. An Integrated Semasiological and Onomasiological Presentation of Semantic Information in General Monolingual Dictionaries as Proposed in H.E. Wiegand's Semantics and Lexicography. Lexikos 10: 119-137.

Ripfel, M. and H.E. Wiegand. 1988. Wörterbuchbenutzungsforschung. Ein kritischer Bericht. Wiegand, H.E. (Ed.). 1986. Studien zur neuhochdeutschen Lexikographie VI, 2. Teilband. Mit einem Namen- und Sachregister zu den Bänden I-VI sowie einer Bibliographie zur Wörterbuchforschung. Germanistische Linguistik 87-90: 490-520. Hildesheim/New York/Zürich: Georg Olms.

Smit, M. 2001. Herbert Wiegand with a "Metalexicographical Panga" in the Jungle: An Unlocking of Wörterbuchforschung. Lexikos 11: 296-310.

Wiegand, H.E. 1977. Nachdenken über Wörterbücher: Aktuelle Probleme. Drosdowki, G., H. Henne, H.E. Wiegand (Eds.). Nachdenken über Wörterbücher: 51-102. Mannheim: Bibliographisches Institut.

Wiegand, H.E. 1983. Überlegungen zu einer Theorie der lexikographischen Sprachbeschreibung. Hyldgaard-Jensen, K. and A. Zettersten (Eds.). 1983. Symposium zur Lexikographie / Symposium on Lexicography. Proceedings of the Symposium on Lexicography, September 1-2 1982, at the Uni- 
versity of Copenhagen. Germanistische Linguistik 5-6: 35-72. Hildesheim/New York: Georg Olms.

Wiegand, H.E. 1984a. Prinzipien und Methoden historischer Lexikographie. Besch, W. et al. (Eds.). 1994. Sprachgeschichte. Ein Handbuch zur Geschichte der deutschen Sprache und ihrer Erforschung: 557-620. Berlin: De Gruyter.

Wiegand, H.E. 1984b. On the Structure and Contents of a General Theory of Lexicography. Hartmann, R.R.K (Ed.). LEXeter '83 Proceedings. Papers from the International Conference on Lexicography at Exeter, 9-12 September 1983: 13-30. Tübingen: Max Niemeyer.

Wiegand, H.E. 1985. Eine neue Auffassung der sog. lexikographischen Definition. Hyldgaard-Jensen, K. and A. Zettersten (Eds.). Symposium on Lexicography II. Proceedings from the Second International Symposium on Lexicography May 16-17 1984 at the University of Copenhagen: 15-100. Tübingen: Max Niemeyer.

Wiegand, H.E. 1989a. Der gegenwärtige Status der Lexikographie und ihr Verhältnis zu anderen Disziplinen. Hausmann, F.J. et al. (Eds.). 1989-1991: 246-280. Berlin: De Gruyter.

Wiegand, H.E. 1989b. Aspekte der Makrostruktur im allgemeinen einsprachigen Wörterbuch: Alphabetische Anordnungsformen und ihre Probleme. Hausmann, F.J. et al. (Eds.). 1989-1991: 371-409.

Wiegand, H.E. 1989c. Der Begriff der Mikrostruktur: Geschichte, Probleme, Perspektiven. Hausmann, F.J. et al. (Eds.). 1989-1991: 409-462.

Wiegand, H.E. 1989d. Arten von Mikrostrukturen im allgemeinen einsprachigen Wörterbuch. Hausmann, F.J. et al. (Eds.). 1989-1991: 462-501.

Wiegand, H.E. 1989e. Die lexikographische Definition im allgemeinen einsprachigen Wörterbuch. Hausmann, F.J. et al. (Eds.). 1989-1991: 530-588.

Wiegand, H.E. 1990. Die deutsche Lexikographie der Gegenwart. Hausmann, F.J. et al. (Eds.). 1989-1991: 2100-2246.

Wiegand, H.E. 1991. Über die Strukturen der Artikeltexte im Frühneuhochdeutschen Wörterbuch. Zugleich ein Versuch zur Weiterentwicklung einer Theorie lexikographischer Texte. Goebel, U. and O. Reichmann (Eds.). 1991. Historical Lexicography of the German Language. Volume 2: 341-673. Lewiston, NY: Edwin Mellen.

Wiegand, H.E. 1992. Elements of a Theory towards a So-called Lexicographic Definition. Lexicographica 8: 175-289.

Wiegand, H.E. 1998. Wörterbuchforschung. Untersuchungen zur Wörterbuchbenutzung, zur Theorie, Geschichte, Kritik und Automatisierung der Lexikographie. 1. Teilband. Mit 159 Abbildungen im Text. Berlin/New York: De Gruyter.

Wiegand, H.E. 1999. Semantics and Lexicography. Selected Studies (1976-1996). Edited by A. Immken and W. Wolski. Tübingen: Max Niemeyer.

Wiegand, H.E. 2000. Kleine Schriften: Eine Auswahl aus den Jahren 1970 bis 1999 in zwei Bänden. Band 1 1970-1988. Band 2 1988-1999. Edited by M. Kammerer and W. Wolski. Berlin/New York: De Gruyter.

Wiegand, H.E. 2002. Zur Aequivalenz in der zweisprachigen Lexikographie. Kritik und Vorschläge. Wiegand, H.E. (Ed.). 2002. Studien zur zweisprachigen Lexikographie mit Deutsch VIII. Germanistische Linguistik 166: 93-110. Hildesheim/New York: George Olms. (English translation: Wiegand, H.E. 2002. Equivalence in Bilingual Lexicography: Criticism and Suggestions. Lexikos 12: 239-255.) 